\title{
Potential Forage of Manihot spp. Under the Effect of Cuts and Sources of Organic Fertilization
}

\author{
Francisco Hugo H. de Alencar ${ }^{1}$, Divan S. da Silva ${ }^{2}$, Alberício P. de Andrade ${ }^{3}$, Riselane de L. A. Bruno ${ }^{2}$, \\ João Luciano de A. Melo Junior ${ }^{3}$, Luan Danilo F. de A. Melo ${ }^{4} \&$ Ariosvaldo N. de Medeiros ${ }^{2}$ \\ ${ }^{1}$ Federal Institute of Ceará, Campus Juazeiro do Norte, Juazeiro do Norte, Ceará, Brazil \\ ${ }^{2}$ Center of Agricultural Sciences, Federal University of Paraíba, Areia, Paraíba, Brazil \\ ${ }^{3}$ Academic Unit of Garanhuns, Federal Rural University of Pernambuco, Garanhuns, Pernambuco, Brazil \\ ${ }^{4}$ Center of Agricultural Sciences, Federal University of Alagoas, Rio Largo, Alagoas, Brazil \\ Correspondence: João Luciano de A. Melo Junior, Academic Unit of Garanhuns, Federal Rural University of \\ Pernambuco, Av. Bom Pastor, s/n, 55292-270, Garanhuns, PE, Brazil. E-mail: luciiano.andrade@yahoo.com.br
}

Received: June 2, 2019 Accepted: July 13, $2019 \quad$ Online Published: September 30, 2019

doi:10.5539/jas.v11n16p30 URL: https://doi.org/10.5539/jas.v11n16p30

\begin{abstract}
Manihot spp. (family Euphorbiaceae), commonly known as pornunça, is a forage plant that has been used in animal feed. This study was conducted to evaluate the effects of different conditions of organic adduction and cuts on the growth, productivity, and partition of aerial phytomass of pornunça in the Brazilian semiarid region. This work is part of a study to discover species of the Brazilian caatinga biome with agricultural potential. An experiment was conducted in the region of Cubatí - PB, Brazil, mesorregion of Borborema, and microregion of Seridó Oriental. The experimental design included randomized blocks with subdivided plots comprising two manure plots (bovine and ovine) and four cut subplots (February, June and October 2011, and February 2012). The sprout height, stem diameter, number of leaves, number of branches, green matter of the complete fraction, leaf green matter, green matter of the petiole, and green matter of the branch were evaluated. For sprout height, stem diameter $(\leq 1.0 \mathrm{~cm})$, green matter of the complete fraction, green matter of leaf limb, green petiole matter, and green matter of the branch, the best results were obtained in the first and second cuts. In contrast, the first and third cuttings allowed the management of a greater number of leaves and a greater number of branches of pornunça using both cattle manure and sheep manure and exhibited a morphophysiological characteristic of adaptation to the xeric environment, being a water deficit tolerant plant.
\end{abstract}

Keywords: animal feed, forage, pornunça, semiarid, water deficit tolerant

\section{Introduction}

The use of native plants as animal fodder in the form of hay, silage, or in natura represents a viable alternative for increasing the availability of food to the herd, primarily at times of the year when the rains are irregular. According to Moreira Filho, Silva, Andrade, Parente, and Viana (2008), the cultivation of native forage in xerophilous agriculture can reduce the risks of production loss due to seasonal fluctuations in precipitation events.

Organic matter is the best indicator of soil quality as its presence is sensitive to the management practices, showing a direct relationship with the stability of the aggregates, soil structure, water infiltration and retention, erosion resistance, biological activity, cation exchange, and nutrient availability (Soares et al., 2018).

The application of animal manure in areas of family agriculture in the Brazilian semiarid region is a common practice, aiming to supply the needs of nutrients, especially nitrogen and phosphorus (Menezes \& Salcedo, 2007) In general, the soils of this region are deficient in $\mathrm{N}$ and $\mathrm{P}$ and have low productivity if nutrient replenishment does not occur (Menezes \& Silva, 2008). P. C. Souto, Santos, Araújo, and L. S. Souto (2005) investigated the decomposition of manures arranged in different depths in a degraded area and confirmed that the highest decomposition rate that occurred during the experimental period was that of bovine and goat manure.

Understanding the processes that comprise the growth of forage plants is the first element in the establishment of rational strategies for the management of pastures (Pereira, Ferreira, \& Guimarães, 2018). According to Andrade, 
Souza, D. S. Silva, I. D. F. Silva, and Lima (2006), plant growth in the semiarid region could be better understood from the viewpoint of "pulses-reserves", regardless of precipitation and/or water reserves in the soil, where a simple and direct relationship occurs between rainfall events (pulses) and primary production.

Manihot spp. is a euphorbiaceous plant and commonly known as pornunça. It is a natural hybrid resulting from the crossing of mandioca (Manihot esculenta Crantz) and maniçoba (M. glaziowii Meull) or (M. pseudoglaziovii Meull Arg.) and found in the Brazilian caatinga biome, xerophyte of forage value (Campos et al., 2019). According to Oliveira et al. (2010), the plant is ecophysiologically adapted to the semiarid soil conditions, tolerant to intense water stresses, produces a large number of leaves that persist in the dry season (strategic advantage), and has good sprouting capacity in the rainy season (two to three pruning per year) after the first year of implantation without pruning.

In a rainfed production system, the amount of aerial part cuts depends on soil moisture, and in the dry season, it provides regrowth as a function of the tuberous root system developed with assimilated reserve sources. Since the first year of cultivation is destined to the development of the root system, the cuts are made successively from the second year onward (Voltolini et al., 2010).

The objective of this study was to evaluate the effect of organic fertilization, bovine and ovine manure, on the vegetative growth, productivity, and partition of aerial phytomass of the pornunça suffering successive cuts in the Brazilian semiarid region, allowing to characterize the physiological differences in the two characteristic seasons of the Northeast Region, the rainy season and the dry season.

\section{Material and Methods}

This study was conducted at the Cumatí farm, located at $6^{\circ} 49^{\prime} 1^{\prime \prime} \mathrm{S}$ and $36^{\circ} 21^{\prime} 38^{\prime \prime} \mathrm{W}$ and at $546 \mathrm{~m}$ altitude, located in the municipality of Cubatí, PB, Brazil, mesorregion of Borborema, and microregion of Seridó Oriental, known as Curimataú paraibano. It presents a BSh climate, hot semiarid, Köppen climatic classification, with rainfall occurring from January to April and an average annual precipitation and temperature of approximately $400 \mathrm{~mm}$ and $26^{\circ} \mathrm{C}$, respectively.

\subsection{Chemical and Fertility Analysis and Physical Characterization}

Soil samples were collected at 0-20 and 20-40 cm depths for chemical and fertility analysis and physical characterization, with 10 simple samples for each depth, yielding two composts for the two depths (Table 1). The soil samples were homogenized and, together with the bovine and ovine manure samples, processed and analyzed according to the methodology adopted by Embrapa (2006) in the laboratories of Chemistry and Soil Fertility and Soil Physics, the Department of Soils and Rural Engineering, the Center for Agricultural Sciences, the Federal University of Paraíba.

Based on the results of analysis shown in Table 1 , the use $20 \mathrm{mg} \mathrm{ha}^{-1}$ of bovine and ovine manure was recommended. Correction and/or addition of macronutrients and/or micronutrients were not performed because the purpose of the study was to assess the effect of organic fertilization on the morphometric and productive parameters of pornunça.

The soil presented a granulometric distribution for depths of 0-20 and 20-40 cm, respectively, with 615 and 559 $\mathrm{g} \mathrm{kg}^{-1}$ of coarse sand, 272 and $330 \mathrm{~g} \mathrm{~kg}^{-1}$ of fine sand, 85 and $77 \mathrm{~g} \mathrm{~kg}^{-1}$ of silt, and 28 and $34 \mathrm{~g} \mathrm{~kg}^{-1}$ of clay, being classified as a regolithic soil, type of soil with sandy texture with high rate of infiltration of water and low capacity of adsorption of nutrients when compared with clayey soils, having low levels of organic matter and nitrogen that decrease after a few years of use being classified as texture as sandy.

\subsection{Climatic Data}

During the experimental period, i.e., April 2010 to April 2012, the precipitation was $914 \mathrm{~mm}$ and the maximum and minimum temperatures were $30.2{ }^{\circ} \mathrm{C}$ and $22{ }^{\circ} \mathrm{C}$, with an average of $26^{\circ} \mathrm{C}$, at the experimental site. Rainfall during the experimental period was concentrated in the months of March to May, with the dry period from August to December (Figure 1). It is noteworthy that in October 2010, there was a rainfall of $120 \mathrm{~mm}$ on 2 days, which is atypical precipitation because the amount of rainfall since the past 15 years in the month of October was only $59 \mathrm{~mm}$.

As shown in Figure 1, from August 2011 to April 2012, there were no rain events, characterizing a long period of drought ( 9 months). These data indicates high annual and monthly variability, typical of the Brazilian semiarid region, that affects the availability of water for the crops under study. 
Table 1. Chemical attributes of soil and manure applied to experimental area

\begin{tabular}{lllll}
\hline Determination & Soil $(0-20 \mathrm{~cm})$ & Soil $(0-40 \mathrm{~cm})$ & Bovine manure & Ovine manure \\
\hline $\mathrm{pH}\left(\mathrm{H}_{2} \mathrm{O} 1: 2.5\right)$ & 6.46 & 6.22 & 9.48 & 8.91 \\
\hdashline$m g d m^{-3}$ & & & & \\
$\mathrm{P}$ & 16.11 & 10.59 & $1,013.6$ & $1,062.7$ \\
$\mathrm{~K}^{+}$ & 54.04 & 51.55 & 3,990 & 2,343 \\
${\text { cmolc } d m^{-3}}^{-3}$ & 0.1 & 0.1 & 9.5 & 5.6 \\
$\mathrm{Na}^{+}$ & 1.32 & 0.83 & 0 & 0.17 \\
$\mathrm{H}^{+}+\mathrm{Al}^{3+}$ & 0 & 0 & 0 & 0 \\
$\mathrm{Al}^{3+}$ & 2.1 & 1.8 & 5.7 & 7.8 \\
$\mathrm{Ca}^{2+}$ & 0.35 & 0.15 & 3.75 & 10.1 \\
$\mathrm{Mg}^{2+}$ & 2.67 & 2.15 & 29.1 & 29.4 \\
$\mathrm{SB}$ & 3.99 & 2.98 & 29.1 & 29.6 \\
$\mathrm{CTC}$ & 3.19 & 2.57 & 237.7 & 290.3 \\
\hline$g \mathrm{Kg}$ & & & & \\
$\mathrm{MO}$ & & &
\end{tabular}

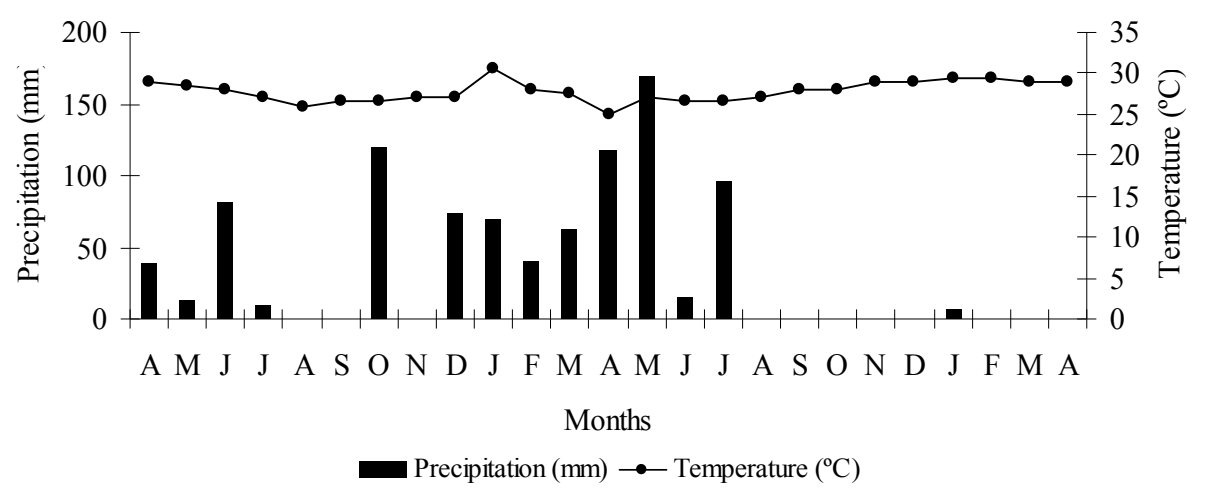

Figure 1. Monthly averages of temperature and precipitation occurred in Cubatí (PB) from April 2010 to April 2012

\subsection{Assays}

The experimental design included randomized blocks with subdivided plots, comprising two manure plots (bovine and ovine) in the primary plot and four cut subplots (February, June and October 2011, and February 2012). The establishment of culture (without cuts) was done during the period from April 2010 to February 2011, with the two organic fertilizers being applied in the months of May 2010 and March 2011 at an amount of $20 \mathrm{mg}$ $\mathrm{ha}^{-1}$.

The experimental unit was formed by three rows of pornunça, resulting in nine plants with a spacing of $1.5 \times 1.5$ $\mathrm{m}$ (4444 plants.ha $\left.{ }^{-1}\right)$, and data were collected from three plants for morphometric analysis, and the remainder constituted the border in plots of $5 \times 5 \mathrm{~m}$.

The planting was carried out using seedlings from the forest nursery of the National Institute of the Semiarid-INSA on March 20, 2010. Data collection began on April 10, 2010. The bovine and ovine manures were distributed in a circular form in the projection of the canopy of the plants. Manual weeding was done as far as the invasion of weeds was concerned, five times in 2010, three times in 2011, and none in 2012.

The definition of the cuttings was based on the phenological stage of the plants, considering appropriate when they were in full development, soon after flowering, and before fruiting, with a mean interval of cuts of 126 days.

Growth assessments were conducted every 30 days, from April 2010 to April 2012. The plant height was measured from the ground level to the highest horizontal plane of the leaves, with a linear meter next to the stem. For statistical analysis, the height of regrowth of the plant was estimated based on the difference between the height of the plant and the height of the cut. The stem diameter was measured at a height of $20 \mathrm{~cm}$ from the 
ground level using a pachymeter, considering the difference between the diameter measured at the end of the cut compared to the beginning as an increase. The number of shoots and leaves was determined by counting.

To determine the production of green matter $\left(\mathrm{kg} \mathrm{ha}^{-1}\right)$, nine plants per plot were cut, occurring to the separation of the material collected from the following four fractions: foliar limbs, petioles, branches ( $\leq 1 \mathrm{~cm}$ in diameter), and complete (sum of the three fractions), because in the study of the production of forage of the aerial part, an important factor to be considered is the partition of the aerial phytomass (Costa et al., 2007).

In total, $300 \mathrm{~g}$ of the sampled material was placed in a paper bag, subjected to predrying in a forced air circulation oven $\left(65^{\circ} \mathrm{C}\right)$ until it reached a constant weight, ground in a mill with $1.0 \mathrm{~mm}$ mesh sieve, and then placed in a closed container, duly identified, for subsequent laboratory analysis. This stage of the work was carried out in the Laboratory of Analysis and Evaluation of Food, the Center of Agricultural Sciences, the Federal University of Paraíba.

\subsection{Statistical Procedure}

The results of the evaluations were submitted to analysis of variance, evaluated by the Bartlett test for homogeneity and by the Kolmogorov-Smirnov test for normality. The variances of the variables that were homogeneous had the factors under study evaluated by the F test, otherwise the transformation was used. When the results showed significance at the $5 \%$ probability level the averages were compared by the Tukey test at the $5 \%$ probability level. All analyses were performed with the statistical software Sisvar version 5.6 (Ferreira, 2014), according to the mathematical model $Y_{\mathrm{ijk}}=\mu+b_{\mathrm{i}}+\mathrm{t}_{\mathrm{j}}+\mathrm{e}_{\mathrm{ij}}+\mathrm{c}_{\mathrm{k}}+\mathrm{e}_{\mathrm{ijk}}$, where, $\mathrm{Y}_{\mathrm{ijk}}=$ independent variable; $\mu$ $=$ average overall; $b_{i}=$ effect of block $i ; i(i=1,2,3,4) ; t_{j}=$ treatment effect $j ; j(j=1,2) ; e_{i j}=$ main plot error; $c$ $=$ cut-off effect $\mathrm{k} ;(\mathrm{k}=1,2,3,4) ; \mathrm{tc}_{\mathrm{jk}}=$ effect of treatment $\mathrm{x}$ cut interaction and $\mathrm{e}_{\mathrm{ijk}}=$ experimental error.

\section{Results and Discussion}

There was no statistical difference $(p>0.05)$ in plant regrowth height and stem diameter increases with the use of bovine and ovine manure, which was probably because the manure mineralization was insufficient due to the irregularity of precipitation after the application of these manures and due to the development of plant defense mechanisms to water stress, since the values decreased in the third and fourth cuts, a period of greater water scarcity. However, the best results were observed for plant regrowth height and stem diameter increases as a function of the first and second cuttings (Table 2).

Ferreira et al. (2009) evaluated the growth, productivity, and chemical-bromatological composition of mandioca, maniçoba, and the natural hybrid pornunça in two pruning systems cultivated in the semiarid region and confirmed that cassava and pornunça exhibited final average heights of 106.8 and $116.4 \mathrm{~cm}$, respectively, at 10 months after planting. Vasconcelos et al. (2010) investigated the morphometry, production, and bromatological composition of maniçoba and pornunça in response to different sources of fertilization and found that there was no interaction between species and fertilization in the production characteristics and morphometric variables evaluated in their study.

Table 3 shows that the number of leaves and the number of branches were greater in the first and third cuts but did not differ statistically as a function of cattle and sheep manure $(p>0.05)$. This was probably because of the best utilization of the water resources by the root system of the plant in the first and third cuts and the absence of precipitation in the period of the fourth cut. In relation to the fourth cut, there may have been a greater translocation of photoassimilates (carbohydrates) to the roots, making it difficult to form aerial architecture.

It is noteworthy that the sum of the number of leaves from the second, third, and fourth cuts was higher than the number of leaves of the first cut, for both cattle manure and sheep manure, because pornunça responds positively to successive cuts, even with irregular distribution of rainfall. In the fourth cut, it rained $7 \mathrm{~mm}$ in 122 days, and in the third cut, $86.5 \%$ of the precipitation was concentrated in 10 days of July 2011 , in a cut interval with 133 days. On the other hand, in the first cut, there was a greater water volume for a period of 310 days. 
Table 2. Sprouting height and stem diameter of Manihot spp. due to organic fertilizers and cuts in the Semiarid

\begin{tabular}{|c|c|c|c|c|c|}
\hline \multirow{2}{*}{ Manure } & \multicolumn{4}{|c|}{ Sprouting height $(\mathrm{cm})$} & \multirow{2}{*}{ Average } \\
\hline & $\mathrm{C} 1$ & $\mathrm{C} 2$ & $\mathrm{C} 3$ & $\mathrm{C} 4$ & \\
\hline Bovine & 65.7 & 64.3 & 37.6 & 19.9 & $46.9 \mathrm{~A}$ \\
\hline Ovine & 78.4 & 63.3 & 35.4 & 19.8 & $49.2 \mathrm{~A}$ \\
\hline Average & $72.1 \mathrm{a}$ & $63.8 \mathrm{a}$ & $36.5 \mathrm{~b}$ & $19.9 \mathrm{c}$ & \\
\hline $\mathrm{CV}(\%)$ & 55.57 & & & & 14.42 \\
\hline \multirow{2}{*}{ Manure } & \multicolumn{4}{|c|}{ Stem diameter $(\mathrm{mm})$} & \multirow{2}{*}{ Average } \\
\hline & $\mathrm{C} 1$ & $\mathrm{C} 2$ & $\mathrm{C} 3$ & $\mathrm{C} 4$ & \\
\hline Bovine & 1.6 & 1.7 & 1.1 & 1.0 & $1.4 \mathrm{~A}$ \\
\hline Ovine & 1.5 & 1.5 & 1.0 & 1.0 & $1.3 \mathrm{~A}$ \\
\hline Average & $1.6 \mathrm{a}$ & $1.6 \mathrm{a}$ & $1.1 \mathrm{~b}$ & $1.0 \mathrm{~b}$ & \\
\hline $\mathrm{CV}(\%)$ & 42.44 & & & & 25.75 \\
\hline
\end{tabular}

Note. Means followed by the same lowercase letter in the column and upper case in the row do not differ from each other to a $5 \%$ probability by the Tukey test.

Table 3. Number of leaves and number of branches of Manihot spp. due to organic fertilizers and cuts in the Semiarid

\begin{tabular}{|c|c|c|c|c|c|}
\hline \multirow{2}{*}{ Manure } & \multicolumn{4}{|c|}{ Number of leaves } & \multirow{2}{*}{ Average } \\
\hline & $\mathrm{C} 1$ & $\mathrm{C} 2$ & C3 & $\mathrm{C} 4$ & \\
\hline Bovine & 103 & 68 & 114 & 23 & $77 \mathrm{~A}$ \\
\hline Ovine & 117 & 60 & 100 & 22 & $75 \mathrm{~A}$ \\
\hline Average & $110 \mathrm{a}$ & $64 \mathrm{~b}$ & $107 \mathrm{a}$ & $23 \mathrm{c}$ & \\
\hline CV $(\%)$ & 130.00 & & & & 31.00 \\
\hline \multirow{2}{*}{ Manure } & \multicolumn{4}{|c|}{ Number of branches } & \multirow{2}{*}{ Average } \\
\hline & $\mathrm{C} 1$ & $\mathrm{C} 2$ & $\mathrm{C} 3$ & $\mathrm{C} 4$ & \\
\hline Bovine & 16 & 12 & 14 & 5 & $12 \mathrm{~A}$ \\
\hline Ovine & 18 & 12 & 14 & 6 & $12 \mathrm{~A}$ \\
\hline Average & $17 \mathrm{a}$ & $12 \mathrm{~b}$ & $14 \mathrm{a}$ & $6 \mathrm{c}$ & \\
\hline $\mathrm{CV}(\%)$ & 112.64 & & & & 24.20 \\
\hline
\end{tabular}

Note. Means followed by the same lowercase letter in the column and upper case in the row do not differ from each other to a $5 \%$ probability by the Tukey test.

For the first cut, the time interval was 310 days after planting, and for the second, third, and fourth cuts, the time intervals were 123, 133, and 122 days after planting, respectively. Apparently, the longer time period in the first cut allowed a larger number of branches in response to a more uniform mineralization of bovine and ovine manure. Araújo Filho et al. (2011) did not observe significant effects of bovine and goat manure on plant height, number of leaves, and stem diameter of maniçoba in their evaluations performed during two cuts, performed at 120 and 240 days after the standardization cut.

Regarding the production of green matter of the complete fraction and the production of green matter of leaf limb, the best results were found in the first and second cuts (Table 4). With the presence of precipitation events, the greatest green matter production of the complete fraction and green matter of leaf limb, in the first and second cuts, occurred under the effect of sheep manure because of the uniform availability of nutrients over time. The manure in the form of "small spheres" allowed a gradual release, whereas in cattle manure, the nutrient release was faster, lacking nutrients in a certain period and reflecting a lower production.

Alencar, Silva, Andrade, Carneiro, and Feitosa (2015) analyzed the chemical composition and digestibility of pork and concluded that pork should be considered as an alternative food for animals on the basis of the values of the chemical composition presented, the leaf limb being the part of the plant that presents the best nutritive value. 
Table 4. Green matter of the complete fraction and green matter of the leaf blade of Manihot spp. due to organic fertilizers and cuts in the Semiarid

\begin{tabular}{|c|c|c|c|c|c|}
\hline \multirow{2}{*}{ Manure } & \multicolumn{4}{|c|}{ Green matter of the complete fraction $\left(\mathrm{Kg} \mathrm{ha}^{-1}\right)$} & \multirow{2}{*}{ Average } \\
\hline & $\mathrm{C} 1$ & $\mathrm{C} 2$ & $\mathrm{C} 3$ & $\mathrm{C} 4$ & \\
\hline Bovine & $7,870.00$ & $8,554.00$ & $4,797.50$ & $5,233.00$ & $6,613.62 \mathrm{~A}$ \\
\hline Ovine & $9,677.00$ & $10,620.50$ & $4,562.50$ & $5,825.00$ & $7,671.25 \mathrm{~A}$ \\
\hline Average & $8,773.50 \mathrm{a}$ & $9,587.25 \mathrm{a}$ & $4,680.06 \mathrm{~b}$ & $5,529.00 \mathrm{~b}$ & \\
\hline $\mathrm{CV}(\%)$ & 42.76 & & & & 35.81 \\
\hline \multirow{2}{*}{ Manure } & \multicolumn{4}{|c|}{ Green matter of the leaf blade $\left(\mathrm{Kg} \mathrm{ha}^{-1}\right)$} & \multirow{2}{*}{ Average } \\
\hline & $\mathrm{C} 1$ & $\mathrm{C} 2$ & $\mathrm{C} 3$ & $\mathrm{C} 4$ & \\
\hline Bovine & $4,385.50$ & $4,863.50$ & $2,079.50$ & $2,544.00$ & $3,468.12 \mathrm{~A}$ \\
\hline Ovine & $5,316.50$ & $6,069.50$ & $1,888.00$ & $2,768.00$ & $4,010.50 \mathrm{~A}$ \\
\hline Average & $4,851.00 \mathrm{a}$ & $5,466.50 \mathrm{a}$ & $1,983.75 \mathrm{~b}$ & $2,656.00 \mathrm{~b}$ & \\
\hline $\mathrm{CV}(\%)$ & 38.55 & & & & 36.82 \\
\hline
\end{tabular}

Note. Means followed by the same lowercase letter in the column and upper case in the row do not differ from each other to a $5 \%$ probability by the Tukey test.

It was verified that the second cut, with 123 days after the planting, allowed greater green matter of the complete fraction and greater green matter of the leaf limb when compared to the first cut, with 310 days after planting. This showed that the pornunça responded significantly to the first cut, even with increased production (second cut), provided there is soil moisture. Such behavior can be explained by the greater transfer of assimilates from the root system to the aerial part. According to Kirchner et al. (2019), there is a linear relation between vegetal production and presence of water in the soil.

Silva, Santos, Oliveira, Moraes, and Santana (2009) evaluated the forage production and the chemical composition of the pornunça in the Semiarid region, and noticed that the forage production of the pornunça varied from 3.54 ton.ha ${ }^{-1}$ in the first year, with only one cut at 27.17 ton.ha $^{-1}$ of original material in the third year with the accomplishment of two annual cuts.

Table 5 shows that the production of green matter of the petiole differed statistically as a function of the first and second cut, and the production of green matter $(\leq 1.0 \mathrm{~cm}$ in diameter $)$ did not present statistical difference between manure and nematode between cuts probably because the branches are less sensitive to water deficiency (which characterized the third and fourth cuts). Independently of water deficit, the green matter production of the leaf limb was superior to the production of green matter of the petiole and the branch.

Table 5. Green matter of the petiole and green matter of the branch of Manihot spp. due to organic fertilizers and cuts in the Semiarid

\begin{tabular}{|c|c|c|c|c|c|}
\hline \multirow{2}{*}{ Manure } & \multicolumn{4}{|c|}{ Green matter of the petiole $\left(\mathrm{Kg} \mathrm{ha}^{-1}\right)$} & \multirow{2}{*}{ Average } \\
\hline & $\mathrm{C} 1$ & $\mathrm{C} 2$ & $\mathrm{C} 3$ & $\mathrm{C} 4$ & \\
\hline Bovine & $1,581.00$ & $1,806.00$ & 658.00 & 965.50 & $1,252.75 \mathrm{~A}$ \\
\hline Ovine & $1,945.00$ & $2,289.00$ & 673.50 & $1,122.00$ & $1,507.37 \mathrm{~A}$ \\
\hline Average & $1,763.00 \mathrm{a}$ & $2,047.75 \mathrm{a}$ & $665.75 \mathrm{~b}$ & $1,043.75 \mathrm{~b}$ & \\
\hline $\mathrm{CV}(\%)$ & 36.28 & & & & 37.46 \\
\hline \multirow{2}{*}{ Manure } & \multicolumn{4}{|c|}{ Green matter of the branch $\left(\mathrm{Kg} \mathrm{ha}^{-1}\right)$} & \multirow{2}{*}{ Average } \\
\hline & $\mathrm{C} 1$ & $\mathrm{C} 2$ & $\mathrm{C} 3$ & $\mathrm{C} 4$ & \\
\hline Bovine & $1,903.50$ & $1,884.00$ & $2,060.00$ & $1,723.50$ & $1,892.75 \mathrm{~A}$ \\
\hline Ovine & $2,415.50$ & $2,362.00$ & $2,001.00$ & $1,935.00$ & $2,153.37 \mathrm{~A}$ \\
\hline Average & $2,159.50 \mathrm{a}$ & $2,073.00 \mathrm{a}$ & $2,030.50 \mathrm{a}$ & $1,829.25 \mathrm{a}$ & \\
\hline $\mathrm{CV}(\%)$ & 55.44 & & & & 37.88 \\
\hline
\end{tabular}

Note. Means followed by the same lowercase letter in the column and upper case in the row do not differ from each other to a $5 \%$ probability by the Tukey test. 
The Caatinga plants have several adaptations to stressful conditions, and the study of these parameters of vital importance for the understanding of semiarid ecosystems.

\section{Conclusions}

Pornunça can be managed with both cattle manure and sheep manure.

Presents a morphophysiological characteristic of adaptation to the xeric environment.

The studied species has an efficient adaptation to water stress.

\section{References}

Alencar, F. H. H., Silva, D. S., Andrade, A. P., Carneiro, M. S. S., \& Feitosa, J. V. (2015). Composição química e digestibilidade da pornunça sob duas fontes de adubação orgânica e cortes. Revista Caatinga, 28(3), 215-222. https://doi.org/10.1590/1983-21252015v28n324rc

Andrade, A. P., Souza, E. S., Silva, D. S., Silva, I. D. F., \& Lima, J. R. S. (2006). Produção animal no bioma caatinga: Paradigmas dos “pulsos-reservas”. Revista Brasileira de Zootecnia, 35(Suplemento), 138-155.

Araújo Filho, J. T., Paes, R. A., Amorim, P. L., Barros, T. S., Silva, R. A., \& Silva, S. C. (2011). Características morfológicas e valor nutritivo da maniçoba submetida a espaçamentos de plantio e adubações. Revista Brasileira de Saúde e Produção Animal, 12(3), 573-582.

Campos, F. S., Carvalho, G. G. P., Santos, E. M., Araújo, G. G. L., Gois, G. C., Rebouças, R. A., ... Perazzo, A. F. (2019). Characteristics of carcass and non-carcass components of lambs fed diets containing silages of forages adapted to the semiarid environment. South African Journal of Animal Science, 49(1), 119-130. https://doi.org/10.4314/sajas.v49i1.14

Costa, N. L., Moura, G. M., Magalhães, J. A., Townsend, C. R., Pereira, R. G., \& Oliveira, J. R. C. (2007). Regimes de cortes em cultivares de mandioca para alimentação animal em Porto Velho, Rondônia, Brasil. Revista Electrónica de Veterinaria, 8(9), 1-7.

Embrapa, Centro Nacional de Pesquisa de Solos. (2006). Sistema brasileiro de classificação de solos (2nd ed., p. 306). Rio de Janeiro: EMBRAPA-SPI.

Ferreira, A. L., Silva, A. F., Pereira, L. G. R., Braga, L. G. T., Moraes, S. A., \& Araújo, G. G. L. (2009). Produção e valor nutritivo da parte aérea da mandioca, maniçoba e pornunça. Revista Brasileira de Saúde e Produção Animal, 10(1), 129-136.

Ferreira, D. F. (2014). Sisvar: A Guide for its Bootstrap procedures in multiple comparisons. Ciência e Agrotecnologia, 38(2), 109-112. https://doi.org/10.1590/S1413-70542014000200001

Kirchner, J. H., Robaina, A. D., Peiter, M. X., Torres, R. R., Mezzomo, W., Ben, L. H. B., ... Pereira, A. C. (2019). Funções de produção e eficiência no uso da água em sorgo forrageiro irrigado. Revista Brasileira de Ciências Agrárias, 14(2), 1-9. https://doi.org/10.5039/agraria.v14i2a5646

Menezes, R. S. C., \& Salcedo, I. H. (2007). Mineralização de N após incorporação de adubos orgânicos em um Neossolo Regolítico cultivado com milho. Revista Brasileira de Engenharia Agrícola e Ambiental, 11(4), 361-367. https://doi.org/10.1590/S1415-43662007000400003

Menezes, R. S. C., \& Silva, T. O. (2008). Mudanças na fertilidade de um Neossolo Regolítico após seis anos de adubação orgânica. Revista Brasileira Engenharia Agrícola e Ambiental, 12(3), 251-257. https://doi.org/ 10.1590/S1415-43662008000300005

Moreira Filho, E. C., Silva, D. S, Andrade, A. P., Parente, H. N., \& Viana, B. L. (2008). Crescimento vegetativo da maniçoba submetida a diferentes manejos de solo, densidade de plantio e alturas de corte. Revista Caatinga, 21(4), 147-153.

Oliveira, V. R., Araújo, F. P., Drumond, M. A., Moreira, J. N., Kiill, L. H. P., Ribeiro, M. F., ... Souza, A. V. (2010). Recursos genéticos e aproveitamento da biodiversidade do semiárido brasileiro. In I. B. Sá, \& P. C. G. Silva (Eds.), Semiárido brasileiro: pesquisa, desenvolvimento e inovação (Cap. 3, pp. 89-123). Petrolina: Embrapa Semiárido.

Pereira, L. F., Ferreira, C. F. C., \& uimarães, R. M. F. (2018). Manejo, qualidade e dinâmica da degradação de pastagens na Mata Atlântica de Minas Gerais-Brasil. Nativa, 6(4), 370-379. https://doi.org/10.31413/ nativa.v6i4.5542 
Silva, A. F., Santos, A. P. G., Oliveira, A. P. D., Moraes, S. A., \& Santana, L. M. (2009). Produção de forragem e composição química da pornunça cultivada em propriedades familiares de Petrolina/PE. Revista Brasileira de Agroecologia, 4(2), 1268-1272.

Soares, M. D. R., Campos, M. C. C., Cunha, J. M., Weckner, F. C., Brito Filho, E., Mantovaneli, B. C., \& Leite, A. F. L. (2018). Variabilidade espacial da estabilidade dos agregados e matéria orgânica do solo em terra preta arqueológica sob pastagem. Revista Gaia Scientia, 12(2), 125-133. https://doi.org/10.22478/ ufpb.1981-1268.2018v12n2.34416

Souto, P. C., Santos, R. V., Araújo, G. T., \& Souto, L. S. (2005). Decomposição de estercos dispostos em diferentes profundidades em área degradada no Semiárido da Paraíba. Revista Brasileira de Ciência do Solo, 29(1), 125-130. https://doi.org/10.1590/S0100-06832005000100014

Vasconcelos, W. A., Santos, E., Edvan, R., Silva, T., Medeiros, G., \& Filho, L. (2010). Morfometria, produção e composição bromatológica da maniçoba e pornunça em resposta a diferentes fontes de adubação. Revista Trópica-Ciências Agrárias e Biológicas, 4(2), 36-43.

Voltolini, T. V., Neves, A. L. A., Guimarães Filho, C., Sa, C. O., Nogueira, D. M., Campeche, D. F. B., ... Moraes, S. A. (2010). Alternativas alimentares e sistemas de produção animal para o semiárido brasileiro. In I. B. Sá, \& P. C. G. Silva (Eds.), Semiárido brasileiro: Pesquisa, desenvolvimento e inovação (Cap. 6, pp. 199-242). Petrolina: Embrapa Semiárido.

\section{Copyrights}

Copyright for this article is retained by the author(s), with first publication rights granted to the journal.

This is an open-access article distributed under the terms and conditions of the Creative Commons Attribution license (http://creativecommons.org/licenses/by/4.0/). 